\title{
PENENTUAN HARI SIDANG DAN PEMANGGILAN PARA PIHAK SERTA PENUNDAAN PELAKSANAAN KEPUTUSAN TATA USAHA NEGARA
}

IRSYADUL FIKRI MANSUR

irsyadul.fikri09@gmail.com

191003600354

\section{UNIVERSITAS EKASAKTI PADANG}

\section{A. PENDAhUluan}

Keberadaan Peradilan Tata Usaha Negara (PTUN) merupakan hal yang penting dan diperlukan dalam sistem pemerintahan yang berdasarkan hukum. Di dalam sistem pemerintahan yang berdasarkan hukum, PTUN itu memiliki fungsi kontrol (judicial control) terhadap pemerintahan. Kontrol yang dijalankan oleh Peradilan TUN menunjukkan ciricirinya yang khusus apabila dibandingkan dengan lembaga kontrol (lembaga pengawas) lainnya, seperti pengawasan fungsional ataupun pengawasan melekat di dalam tubuh lembaga administrasi (internal control), ataupun pengawasan politis oleh lembaga perwakilan rakyat.

Peradilan Tata Usaha Negara menjadi tempat penyelesaian sengketa administrasi negara yang melaksanakan fungsi untuk menyelenggarakan urusan pemerintah baik pusat maupun di daerah, yaitu menyelesaikan sengketa antara pemerintah dengan warga negaranya dan 
pembentukan lembaga tersebut bertujuan mengkontrol secara yuridis (Judicial Control) tindakan pemerintah yang dinilai melanggar ketentuan Administrasi (Mal Administrasi) ataupun perbuatan yang bertentangan dengan hukum (Abuse of Power).

Menyadari sepenuhnya peran positif aktif Pemerintah dalam kehidupan masyarakat. Maka Pemerintah perlu mempersiapkan langkah untuk menghadapi kemungkinan timbulnya pembentukan kepentingan perselisihan, atau sengketa antara Badan atau pejabat Tata Usaha dengan warga masyarakat. Dengan demikian Peradilan Tata Usaha negara merupakan "control of the administration". Peradilan Tata Usaha negara adalah salah satu pelaksanaan kehakiman bagi rakyat pencari keadilan terhadap sengketa Tata Usaha Negara.

Dalam hukum acara Peradilan TUN berlaku suatu asas rechtmatig (vermoeden van rechtmatigheid, praesumptio iustae causal). Asas ini mengandung makna bahwa setiap tindakan penguasa selalu harus dianggap rechtmatig sampai ada pembatalannya. Dengan asas ini berarti suatu gugatan yang diajukan tidak akan menunda pelaksanaan keputusan TUN yang sedang digugat, bahwa selama suatu keputusan TUN itu tidak digugat dan tidak dinyatakan batal, maka dia selalu dianggap sah menurut hukum dan karenanya selalu dapat dilaksanakan seketika.

Suatu gugatan TUN pada prinsipnya tidak bersifat menunda pelaksanaan keputusan TUN. Namun dari segi perlindungan hukum, dalam keadaan tertentu, penggugat dapat mengajukan permohonan agar selama proses pemeriksaan sengketa berjalan, keputusan TUN yang digugat dapat ditunda pelaksanaannya.

Dengan ini maka penulis melakukan kajian secara mendalam tentang "Penentuan Hari Sidang dan Pemanggilan Para Pihak Serta Penundaan Pelaksanaan Keputusan Tata Usaha Negara". 


\section{B. PEMBAHASAN}

Penentuan hari pelaksanaan dan pemanggilan para pihak dalam sidang keputusan tata usaha negara penentuan hari pelaksanaan dan pemanggilan para pihak dalam sidang keputusan Tata Usaha Negara berkaitan dengan hukum acara yang terbagi atas tiga macam yaitu, acara cepat, acara singkat, dan acara biasa. Terdapat perbedaan antara hukum acara bukan biasa dengan hukum acara biasa.

Apabila kedua acara itu dibandingkan, ternyata masing-masing memiliki proses tersendiri yang berbeda terutama dari faktor waktu. Berdasarkan acara bukan biasa, pemeriksaan perkara-perkara di peradilan Tata Usaha Negara dapat dilaksanakan melalui acara cepat dan acara singkat.

1. Acara Cepat.

Acara cepat diatur di dalam UndangUndang No.5 Tahun 1986 Tentang Peradilan Tata Usaha Negara Pasal 98 ayat (1) menyebutkan:

“ Apabila terdapat kepentingan penggugat yang mendesak yang harus dapat disimpulkan dari alasan-alasan pemohonnya, penggugat dalam gugatannya dapat memohon kepada Pengadilan supaya pemeriksaan sengketa dipercepat”.

Ciri khas acara cepat yaitu:

a. Pemeriksaan dilakukan oleh hakim tunggal.

b. Prosesnya dengan meniadakan prosedur pemeriksaan persiapan.

c. Tidak ada upaya hukum.

d. Waktu untuk jarak antara pemanggilan serta hari sidang tidak boleh kurang dari enam hari, pemeriksaan dipersempit yaitu sejak gugatan didaftar sampai degan pembuktian selesai berlangsung selama 35 hari dengan rincian : 14 hari setelah diterima 
permohonan ketua Pengadilan Tata Usaha Negara. Lalu 7 hari setelah dikeluarkannya penetapan ketua Pengadilan Tata Usaha Negara menentukan hari, tempat, dan waktu sidang. Kemudian 14 hari untuk jawaban dan pembuktian bagi kedua belah pihak. Jarak waktu untuk putusan dipercepat.

e. Bentuk akhir putusan adalah putusan atau vonis.

2. Acara Singkat.

Acara singkat diatur dalam UndangUndang No.5 Tahun 1986 Tentang Peradilan Tata Usaha Negara Pasal 62 ayat (4) menyebutkan:

"Perlawanan sebagaimana dimaksud dalam ayat (3) diperiksa dan diputus oleh Pengadilan dengan acara singkat".

Acara singkat ini tidak untuk menyelesaikan pokok sengketa. Bentuk akhir berupa penetapan. Alasan untuk acara singkat antara lain:

a. Perlawanan (Verzet). Perlawanan merupakan reaksi atas hasil pemusyawaratan yang berupa penolakan. Diajukan dalam tengang waktu 14 hari setelah diucapkannya penetapan Ketua Pegadilan Tata Usaha Negara yang berisi hasil rapat pemusyawaratan.

b. Keadaan yang mendesak.

c. Keadaan yang mendesak ini berlaku bagi penundaan pelaksanaan Keputusan Badan atau Pejabat Tata Usaha Negara. Pada keadaan normal, gugatannya pada prinsipnya tidak menunda pelaksanaan keputusan tersebut.

3. Acara Biasa.

Gugatan Sebagaimana di dalam UndangUndang No. 5 Tahun 1986 Tentang Peradilan Tata Usaha Negara Pasal 1 angka 5 menyebutkan: 
" Gugatan adalah permohonan yang berisi tuntutan terhadap badan atau pejabat tata usaha negara dan diajukan ke pengadilan untuk mendapatkan putusan"

Gugatan di Peradilan Tata Usaha Negara diajukan oleh seseorang atau Badan Hukum Perdata yang merasa kepentingannnya dirugikan akibat dikeluarkannya suatu Keputusan Tata Usaha Negara.

Berhubung sengketa tata usaha negara selalu berkaitan degan keputusan tata usaha negara, maka pengajuan gugatan ke pengadilan dikaitkan pula dengan waktu dikeluarkannya keputusan yang bersangkutan. Berdasarkan UndangUndanng No.5 Tahun 1986 Tentang Peradilan Tata Usaha Negara Pasal 55 menyebutkan:

"Gugatan dapat diajukan hanya dalam tenggang waktu 90 (sembilan puluh) hari terhitung sejak saat diterimanya atau diumumkannya Keputusan Badan dan atau Pejabat Tata Usaha Negara yang bersangkutan".

Dalam praktik Peradilan Tata Usaha Negara di Indonesia Penundaan pelaksanaan Keputusan Tata Usaha Negara lebih populer dengan istilah schorsing, yaitu suatu tindakan atau sikap yang diambil oleh Pengadilan Tata Usaha Negara, dalam hal ini bisa dilakukan oleh Ketua/Wakil Ketua Pengadilan Tata Usaha Negara, Majelis Hakim, Hakim Tunggal atas dasar permohonan dari pihak penggugat untuk menunda pelaksanaan Keputusan Tata Usaha Negara yang menjadi obyek sengketa selama pemeriksaan sengketa berlangsung sampai pada putusan pengadilan yang memperoleh kekuatan hukum tetap yang dituangkan dalam bentuk penetapan.

Penetapan penundaan pelaksanaan sebuah Keputusan Tata Usaha Negara diatur dalam Pasal 67 ayat (2) Undang - Undang Nomor 5 Tahun 1986 yang berbunyi : 
"Penggugat dapat mengajukan permohonan agar pelaksanaan Keputusan Tata Usaha Negara itu ditunda selama pemeriksaan sengketa Tata Usaha Negara sedang berjalan, sampai ada putusan Pengadilan yang memperoleh kekuatan hukum tetap.”

Pada ketentuan pasal diatas memberikan kesempatan kepada penggugat untuk mengajukan penundaan pelaksanaan terhadap sebuah KTUN. Dalam proses pengajuannya, penundaan pelaksanaan dapat dikabulkan sebagaimana yang diatur dalam ketentuan Pasal 67 ayat (4) huruf a yang menyatakan bahwa :

"Dapat dikabulkan hanya apabila terdapat keadaan yang sangat mendesak Yang mengakibatan kepentingan penggugat sangat dirugikan jika Keputusan Tata Usaha negara yang digugat itu tetap dilaksanakan.”

Dalam ketentuan pasal diatas menerangkan bahwa harus ada keadaan yang sangat mendesak dalam permohonan penundaan pelaksanaan. Dapat diilustrasikan, apabila sebuah KTUN sudah dilaksanakan, terdapat pihak yang merasa dirugikan lalu mengajukan gugatan hingga keluar Putusan Pengadilan Tata Usaha Negara yang sudah berkekuatan hukum tetap dangan menyatakan KTUN tidak sah, namun KTUN yang menjadi sengketa sudah dilaksanakan dan untuk pemulihannya memerlukan biaya yang tidak sedikit. Dalam teknis pengajuannya dapat diajukan secara langsung bersamaan dengan gugatan dan terpisah dengan gugatan. Kemudian hasil dari pengajuan tersebut adalah sebuah Penetapan yang dikeluarkan oleh Pengadilan Tata Usaha Negara dengan menyatakan apakah pengajuan permohonan penundaan pelaksanaan dikabulkan atau tidak.

Penundaan pelaksanaan diajukan apabila dalam proses pengajuan gugatan dan proses di Pengadilan Tata Usaha Negara sedang berlangsung, akan tetapi didasarkan pada asas praduga 
rechmatig KTUN akan tetap dijalankan. Apabila KTUN terlanjur dijalankan dengan mengakibatkan kerugian materiil yang cukup besar, namun pada akhirnya gugatan dikabulkan dan putusan menyatakan bahwa KTUN tersebut dibatalkan, keadaan yang seperti inilah sebuah penetapan penundaan pelaksanaan diperlukan untuk memberikan perlindungan kepada penggugat.

C. Penutup

Pengaturan hukum sistem pemriksaan dalam Peradilan Tata Usaha Negara adalah tempat penyelesaian sengketa administrasi negara yang melaksanakan fungsi untuk menyelenggarakan urusan pemerintah baik pusat maupun di daerah, yaitu menyelesaikan sengketa antara pemerintah dengan warga negaranya yang timbul akibat dikeluarkannya Keputusan Tata Usaha Negara yang berakibat kerugian terhadap seseorang ataupun badan hukum perdata.

Penentuan hari pelaksanaan dan pemanggilan para pihak dalam sidang keputusan tata usaha negara penentuan hari pelaksanaan dan pemanggilan para pihak dalam sidang keputusan Tata Usaha Negara berkaitan dengan hukum acara yang terbagi atas tiga macam yaitu, acara cepat, acara singkat, dan acara biasa. Terdapat perbedaan antara hukum acara bukan biasa dengan hukum acara biasa.

Apabila kedua acara itu dibandingkan, ternyata masing-masing memiliki proses tersendiri yang berbeda terutama dari faktor waktu. Berdasarkan acara bukan biasa, pemeriksaan perkara-perkara di peradilan Tata Usaha Negara dapat dilaksanakan melalui acara cepat dan acara singkat. 
Gugatan di Peradilan Tata Usaha Negara diajukan oleh seseorang atau Badan Hukum Perdata yang merasa kepentingannnya dirugikan akibat dikeluarkannya suatu Keputusan Tata Usaha Negara. Berhubung sengketa tata usaha negara selalu berkaitan degan keputusan tata usaha negara, maka pengajuan gugatan ke pengadilan dikaitkan pula dengan waktu dikeluarkannya keputusan yang bersangkutan.

Penundaan pelaksanaan keputusan tata ussaha negara, sebagaimana yang diatur dalam Pasal 67 Undang-Undang Nomor 5 Tahun 1986, dapat dipahami sebagai salah satu wujud perlindungan hukum bagi hak-hak warga masyarakat ketika berhadapan dengan kekuasaan yang ada di tangan pemerintah. Akibat hukum dari penetapan penundaan pelaksanaan keputusan Tata Usaha Negara yang sedang digugat adalah menunda dengan seketika bekerjanya keputusan Tata Usaha Negara itu.

\section{DAFTAR PUSTAKA}

Darmini Roza dan Laurensius Arliman S Peran Pemerintah Daerah Di Dalam Melindungi Hak Anak Di Indonesia, Masalah-Masalah Hukum, Volume 47, Nomor 1, 2018.

Laurensius Arliman S, Komnas HAM dan Perlindungan Anak Pelaku Tindak Pidana, Deepublish, Yogyakarta, 2015.

Laurensius Arliman S, Penguatan Perlindungan Anak Dari Tindakan Human Trafficking Di Daerah Perbatasan Indonesia, Jurnal Selat, Volume 4, Nomor 1, 2016.

Laurensius Arliman S, Problematika Dan Solusi Pemenuhan Perlindungan Hak Anak Sebagai Tersangka Tindak Pidana Di Satlantas Polresta Pariaman, Justicia Islamica, Volume 13, Nomor 2, 2016. 
Laurensius Arliman S, Pelaksanaan Perlindungan Anak Yang Tereksploitasi Secara Ekonomi Oleh Pemerintah Kota Padang, Veritas et Justitia, Volume 2, Nomor 1, 2016.

Laurensius Arliman S, Kedudukan Ketetapan MPR Dalam Hierarki Peraturan Perundang-Undangan Di Indonesia, Lex Jurnalica, Volume 13, Nomor 3, 2016.

Laurensius Arliman S, Komnas Perempuan Sebagai State Auxialiary Bodies Dalam Penegakan Ham Perempuan Indonesia, Justicia Islamica, Volume 14, Nomor 2, 2017.

Laurensius Arliman S, Peranan Pers Untuk Mewujudkan Perlindungan Anak Berkelanjutan Di Indonesia, Jurnal Ilmu Hukum Tambun Bungai, Volume 2, Nomor 2, 2017.

Laurensius Arliman S, Mewujudkan Penegakan Hukum Yang Baik Untuk Mewujudkan Indonesia Sebagai Negara Hukum, Jurnal Hukum Doctrinal, Volume 2, Nomor 2, 2017.

Laurensius Arliman S, Participation Non-Governmental Organization In Protecting Child Rights In The Area Of Social Conflict, The 1st Ushuluddin and Islamic Thought International Conference (Usicon), Volume 1, 2017.

Laurensius Arliman S, Partisipasi Masyarakat Dalam Pembentukan Perundang-Undangan Untuk Mewujudkan Negara Kesejahteraan Indonesia, Jurnal Politik Pemerintahan Dharma Praja, Volume 10, Nomor 1, 2017, https://doi.org/10.33701/jppdp.v10i1.379.

Laurensius Arliman S, Peran Komisi Perlindungan Anak Indonesia Untuk Mewujudkan Perlindungan Anak, Jurnal Respublica Volume 17, Nomor 2, 2018.

Laurensius Arliman S, Menjerat Pelaku Penyuruh Pengrusakan Barang Milik Orang Lain Dengan Mempertimbangkan Asas Fungsi Sosial, Jurnal Gagasan Hukum, Volume 1, Nomor 1, 2019.

Laurensius Arliman S, Ilmu Perundang-Undangan Yang Baik Untuk Negara Indonesia, Deepublish, Yogyakarta, 2019. 
Laurensius Arliman S, Isdal Veri, Gustiwarni, Elfitrayenti, Ade Sakurawati, Yasri, Pengaruh Karakteristik Individu, Perlindungan Hak Perempuan Terhadap Kualitas Pelayanan Komnas Perempuan Dengan Kompetensi Sumber Daya Manusia Sebagai Variabel Mediasi, Jurnal Menara Ekonomi: Penelitian dan Kajian Ilmiah Bidang Ekonomi, Volume 6, Nomor 2, 2020.

Laurensius Arliman S, Pendidikan Kewarganegaraan, Deepublish, Yogyakarta, 2020.

Laurensius Arliman S, Makna Keuangan Negara Dalam Pasal Pasal 23 E Undang-Undang Dasar 1945, Jurnal Lex Librum, Volume 6, Nomor 2 Juni 2020, http://dx.doi.org/10.46839/lljih.v6i2.151.

Laurensius Arliman S, Kedudukan Lembaga Negara Independen Di Indonesia Untuk Mencapai Tujuan Negara Hukum, Kertha Semaya Journal Ilmu Hukum, Volume 8, Nomor 7, 2020.

Laurensius Arliman S, Pelaksanaan Assesment Oleh Polres Kepulauan Mentawai Sebagai Bentuk Pelaksanaan Rehabilitasi Bagi Pecandu Dan Korban Penyalahgunaan Narkotika, Jurnal Muhakkamah, Volume 5, Nomor 1, 2020.

Laurensius Arliman S, Aswandi Aswandi, Firgi Nurdiansyah, Laxmy Defilah, Nova Sari Yudistia, Ni Putu Eka, Viona Putri, Zakia Zakia, Ernita Arief, Prinsip, Mekanisme Dan Bentuk Pelayanan Informasi Kepada Publik Oleh Direktorat Jenderal Pajak, Volume 17, No Nomor, 2020.

Larensius Arliman S, Koordinasi PT. Pegadaian (Persero) Dengan Direktorat Reserse Narkoba Polda Sumbar Dalam Penimbangan Barang Bukti Penyalahgunaan Narkotika, UIR Law Review, Volume 4, Nomor 2, 2020, https://doi.org/10.25299/uirlrev.2020.vol4(1).3779.

Laurensius Arliman S, Tantangan Pendidikan Kewarganegaraan Pada Revolusi 4.0, Ensiklopedia Sosial Review, Volume 2, Nomor 3, 2020. 
Muhammad Afif dan Laurensius Arliman S, Protection Of Children's Rights Of The Islamic And Constitutional Law Perspective Of The Republic Of Indonesia, Proceeding: Internasional Conference On Humanity, Law And Sharia (Ichlash), Volume 1, Nomor 2, 2020.

Otong Rosadi danLaurensius Arliman S, Urgensi Pengaturan Badan Pembinaan Idelogi Pancasila Berdasarkan Undang-Undang Sebagai State Auxiliary Bodies yang Merawat Pancasila dalam Perspektif Hak Asasi Manusia, Prosiding Konferensi Nasional Hak Asasi Manusia, Kebudayaan dan Tujuan Pembangunan Berkelanjutan Indonesia pada Masa Pandemi Covid-19: Tantangan untuk Keilmuan Hukum dan Sosial Volume 1, Universitas Pancasila, Jakarta, 2020. 